\title{
Evaluasi Progam Kemitraan Antara PT Gombek Boer Indonesia Dan Kelompok Peternak Kambing (Studi Kasus Kelompok Peternak Kambing Kecamatan Doko, Kabupaten Blitar)
}

\section{Evaluation of Partnership Progam Between PT Gombek Boer Indonesia and Goat Farmers ( Case Study of Goat Farmer Groups Doko Sub-District, Blitar District)}

\author{
Dita Novarina Gunawati ${ }^{1 *}$, Siti Azizah ${ }^{2}$, and Umi Wisapti Ningsih ${ }^{2}$ \\ ${ }^{1}$ Master Student, Faculty of Animal Husbandry, University of Brawijaya, \\ Malang, East Java, Indonesia-65145 \\ ${ }^{2}$ Department of Socio-economic, Faculty of Animal Husbandry, University of Brawijaya, \\ Malang, East Java, Indonesia-65145 \\ * Corresponding author: ditanovarinagunawatil@gmail.com
}

\begin{abstract}
ABSTRAK
Penelitian ini bertujuan untuk mengetahui tingkat ketercapaian progam kemitraan antara PT Gombek Boer Indonesia dengan peternak kambing di Desa Resapombo. Tempat penelitian dilaksanakan di Kecamatan Doko, Kabupaten Blitar berdasarkan metode purposive sampling. Pengambilan sampel peternak untuk evaluasi kemitraan PT Gombek Boer menggunakan metode total sampling. Metode analisis data menggunakan metode evaluasi CIPP (context, input, process, product). Hasil penelitian evaluasi context kemitraan PT Gombek Boer Indonesia mendapat nilai baik kecuali pada perencanaan progam pelatihan dan pembinaan peternak. Evaluasi input yang mendapatkan nilai buruk yaitu adanya komunikasi terbuka antara peternak dengan perusahaan mitra. Evaluasi process kesesuaian pelaksanaan kemitraan dan pengawasan lapang oleh PPL mendapat nilai buruk. Evaluasi product mendapat nilai baik kecuali ketepatan pembelian hasil ternak.
\end{abstract}

Kata Kunci : Kemitraan, Evaluasi CIPP, Kambing Boer

\section{ABSTRACT}

This study aims to determine the level of achievement of the partnership program between PT Gombek Boer Indonesia and goat farmers in Resapombo Village. The research was conducted in Doko District, Blitar, based on the purposive sampling method. Farmer sample collection for the evaluation of the PT Gombek Boer partnership using the total sampling method. The data analysis method uses the CIPP evaluation method (context, input, process, product). The results of the evaluation study on the partnership context of PT Gombek Boer Indonesia received good grades except on the planning of training programs and fostering farmers. Evaluation of inputs that get a bad score is open communication between farmers and partner companies. The evaluation suitability of the partnerships implementation and field supervision by PPL received a bad score. Product evaluation gets good grades except the accuracy of purchasing livestock products.

Key Words : Partnership Program, CIPP Evaluation, Boer Goat. 


\section{PENDAHULUAN}

Subsektor peternakan terus berupaya memberikan peningkatan kontribusi terhadap perkembangan Produk Domestik Bruto (PDB) di Indonesia setiap tahunnya. Hal ini dilihat dari data PDB sub sektor peternakan tahun 2016 triwulan III sebesar $3.18 \%$ dengan nilai Rp. $36.4 \mathrm{~T}$ mengalami peningkatan setiap tahunya yang terbukti pada catatan triwulan III tahun 2017 sebesar 6,34\% (Direktorat Jenderal Peternakan dan Kesehatan Hewan, 2017).

Kambing merupakan salah satu komunitas ternak yang berpotensi dikembangkan untuk menyokong persediaan protein hewani. Menurut Makka (2004) kebutuhan modal yang diperlukan untuk kambing juga jauh lebih rendah dibandingkan untuk ternak ruminansia besar seperti dapi dan kerbau. Ternak kambing sudah lama diketahui sebagai ternak yang diusahakan oleh petani miskin karena cocok dipelihara di daerah kering dengan kualitas tanah yang sangat marginal. Salah satu jenis kambing yang banyak digemari peternak saat ini yaitu kambing Boerja. Syawal (2010) menyatakan bahwa persilangan merupakan salah satu cara atau upaya untuk meningkatkan produktivitas ternak lokal melalui perkawinan dengan ternak lain yang dianggap memiliki keunggulan tertentu. Kecamatan Doko merupakan salah satu sentra pengembangan peternakan kambing di Kabupaten Blitar, menurut data BPS 2017 tercatat jumlah populasi kambing sebanyak 21.671 ekor. GAPOKTAN Kecamatan Doko saat ini berkerjasama dengan salah satu perusahaan kemitraan kambing Boer yaitu PT Gombek Boer Indonesia. Hafsah (2000) menyatakan bahwa kemitraan usaha adalah kerjasama usaha antara usaha kecil (termasuk petani dan nelayan) dengan usaha menengah atau dengan usaha besar dengan memperhatikan prinsip saling memerlukan, dan saling menguntungkan, diharapkan dari progam kemitraan yang dilakukan oleh PT Gombek Boer Indonesia dengan GAPOKTAN dan peternak kambing dapat membantu meningkatkan pendapatan peternak. Sementara untuk pihak PT Gombek Boer Indonesia sendiri diharapkan dapat merasakan manfaat melalui kemitraan dengan kepastian kontinuitas pasokan ternak.
Menurut Zakaria (2015) Sistem kemitraan usaha antara pengusaha kecil dan pengusaha besar berdampak besar bagi peningkatan pertumbuhan ekonomi penyerapan tenaga kerja, serta pemerataan pendapatan dan mengembangkan pertumbuhan pembangunan regional. Awal berdiri tahun 2016 jumlah anggota mencapai 475 peternak, pada tanggal 1 Oktober 2018 tercatat peternak yang ikut kemitraan menurun menjadi 455 peternak dan selama pelaksanaan kemitraan kambing Boerja ini berjalan hingga bulan Maret 2019 jumlah peternak yang mengikuti kemitraan menurun menjadi 63 peternak. Terjadinya penurunan jumlah peternak yang mengikuti progam kemitraan dapat dilihat dari evaluasi progam kemitraan mulai dari perencanaan progam kemitraan, proses hingga hasil dari progam kemitraan tersebut. Dari hasil evaluasi akan terlihat dari bagian mana yang kurang tepat sehingga pihak perusahaan dapat memperbaiki kinerja. Hal inilah yang melatarbelakangi peneliti melakukan penelitian yang berjudul evaluasi program kemitraan antara PT. Gombek Boer Indonesia dan kelompok peternak kambing.

\section{MATERI DAN METODE}

Penelitian dilakukan pada tanggal 20 Maret- 20 April 2019. Tempat penelitian dilaksanakan di Kecamatan Doko, Kabupaten Blitar berdasarkan metode purposive atau secara sengaja. Pemilihan Kecamatan Doko sebagai tempat penelitian dikarenakan Kecamatan Doko merupakan salah satu sentra pengembangan peternakan kambing di Kabupaten Blitar, menurut data BPS 2017 tercatat jumlah populasi kambing sebanyak 21.671 ekor. Selain itu PT Gombek Boer Indonesia pertama kali melakukan kemitraan bekerjasama dengan GAPOKTAN di Kecamatan Doko.

Penelitian ini menggunakan pendekatan mixed method, yaitu kombinasi dari pendekatan kuantitatif dan kualitatif. Metode penelitian menggunakan metode survei untuk memperoleh data primer dan sekunder. Data primer merupakan data yang didalamnya terdapat daftar-daftar pertanyaan untuk memperoleh informasi secara langsung dari PT Gombek Boer Indonesia dan peternak 
melalui kuesioner. Analisis data menggunakan CIPP (context, input, process, product). Muryadi (2017) menjelaskan Model CIPP (Context, Input, Process, dan Product) merupakan model evaluasi di mana evaluasi dilakukan secara keseluruhan sebagai suatu sistem. Pengambilan sampel peternak untuk evaluasi kemitraan PT Gombek Boer menggunakan metode total sampling berdasarkan dari jumlah data peternak yang bergabung dalam kemitraan PT Gombek Boer
Indonesia di Desa Resapombo yang berjumlah 63 peternak.

\section{HASIL DAN PEMBAHASAN Evaluasi context}

Evaluasi context merupakan salah satu variabel yang mengamati tentang perencanaan kemitraan sejauh mana kesesuaian tujuan yang sudah ditetapkan terhadap kebutuhan-kebutuhan dari peternak. Berikut adalah tabel hasil dari evaluasi context.

Tabel 1. Evaluasi context kemitraan PT Gombek Boer Indonesia

\begin{tabular}{|c|c|c|c|c|c|c|}
\hline \multirow{2}{*}{$\mathrm{X}_{1}$ (Context) } & \multicolumn{4}{|c|}{ Skor Likert } & \multicolumn{2}{|c|}{ Rata-rata } \\
\hline & 1 & 2 & 3 & 4 & 5 & \\
\hline $\mathrm{X}_{1.1}$ Perencanaan kemitraan & - & - & - & 40 & 23 & 4,36 \\
\hline $\begin{array}{l}\mathrm{X}_{1.2} \text { Perencanaan progam pelatihan dan } \\
\text { pembinaan peternak }\end{array}$ & 39 & 24 & - & - & - & 1,38 \\
\hline $\begin{array}{l}\mathrm{X}_{1.3} \text { Perencanaan penyediaan sarana dan } \\
\text { prasarana penunjang kemitraan }\end{array}$ & - & - & - & 9 & 54 & 4,85 \\
\hline $\mathrm{X}_{1.4}$ Perencanaan penetapan harga beli ternak & - & - & - & 40 & 23 & 4,31 \\
\hline $\begin{array}{l}\mathrm{X}_{1.5} \text { Perencanaan pemasaran ternak hasil } \\
\text { kemitraan }\end{array}$ & 42 & 21 & - & - & - & 1,33 \\
\hline Rata-rata & & & & & & 3,25 \\
\hline $\begin{array}{l}1=\text { sangat buruk } \\
3=\text { cukup baik } \\
5=\text { sangat baik }\end{array}$ & $\begin{array}{l}2=\text { bur } \\
4=\text { bai }\end{array}$ & & & & & \\
\hline
\end{tabular}

Kesiapan peternak terhadap progam kemitraan yang ditawarkan oleh PT Gombek Boer Indonesia mencakup kesediaan peternak dalam menjalankan seluruh isi surat perjanjian kemitraan. Nilai rata-rata yang diberikan oleh peternak sebesar 4,11. Peternak yang telah mendaftar kemitraan siap menjalankan progam kemitraan PT Gombek Boer Indonesia meskipun tanpa menandatangani surat perjanjian, peternak lebih mengedepankan keuntungan yang ditawarkan oleh PT Gombek Boer Indonesia. Menurut Mulyani (2017) yang mengatakan bahwa idealnya suatu kemitraan disertai dengan kontrak perjanjian kerjasama secara tertulis yang memuat hak dan kewajiban masing-masing pihak yang bermitra.

Komunikasi yang dilakukan PT Gombek Boer Indonesia dengan peternak mitra selama ini jarang dilakukan hanya sebatas jika ada permasalahan saja. Hasil penelitian rata- rata dari penilaian peternak adalah 2,79 untuk komunikasi. Pertemuan rutin berupa pembinaan peternak untuk saat ini memang belum dilakukan. Komunikasi yang terjalin selama ini hanya sebatas ketika peternak mendapat kendala dalam peternakannya.

\section{Evaluasi input}

Evaluasi input merupakan evaluasi guna melihat sejauh mana perusahaan dapat mengidenfitikasi sumber daya manusia yang ada dan pemenuhan kebutuhan peternak. Tabel berikut menunjukkan hasil dari kedua indikator dalam variabel input: 
Tabel 2. Evaluasi input kemitraan PT Gombek Boer Indonesia

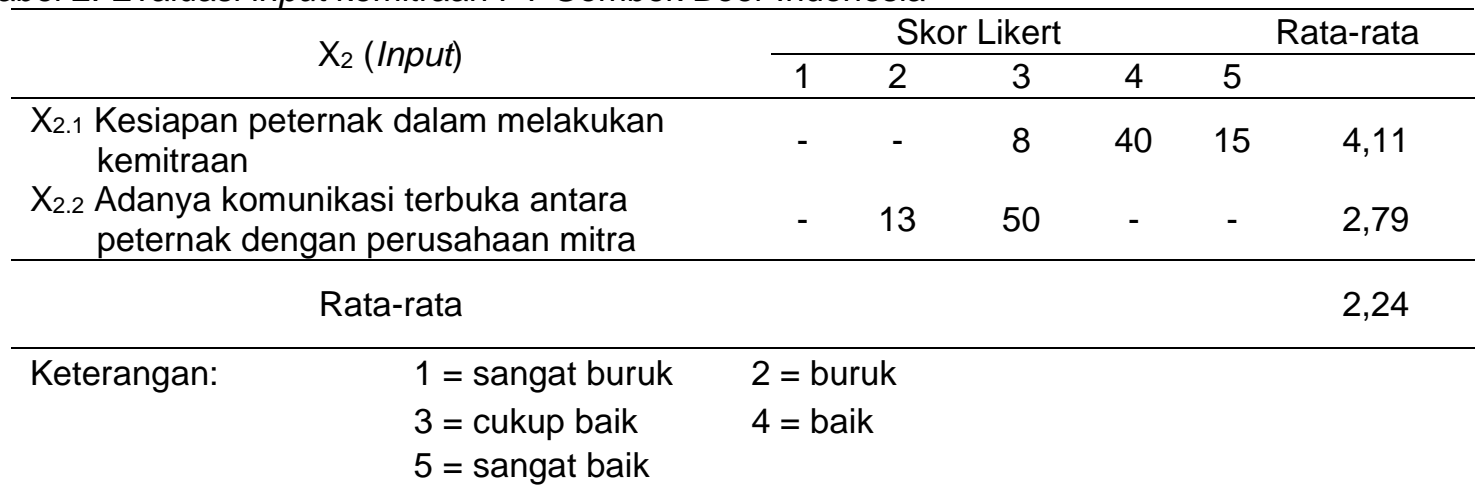

Kesiapan peternak terhadap progam kemitraan yang ditawarkan oleh PT Gombek Boer Indonesia mencakup kesediaan peternak dalam menjalankan seluruh isi surat perjanjian kemitraan. Nilai rata-rata yang diberikan oleh peternak sebesar 4,11. Peternak yang telah mendaftar kemitraan siap menjalankan progam kemitraan PT Gombek Boer Indonesia meskipun tanpa menandatangani surat perjanjian, peternak lebih mengedepankan keuntungan yang ditawarkan oleh PT Gombek Boer Indonesia. Menurut Mulyani (2017) yang mengatakan bahwa idealnya suatu kemitraan disertai dengan kontrak perjanjian kerjasama secara tertulis yang memuat hak dan kewajiban masing-masing pihak yang bermitra.
Komunikasi yang dilakukan PT Gombek Boer Indonesia dengan peternak mitra selama ini jarang dilakukan hanya sebatas jika ada permasalahan saja. Hasil penelitian rata- rata dari penilaian peternak adalah 2,79 untuk komunikasi. Pertemuan rutin berupa pembinaan peternak untuk saat ini memang belum dilakukan. Komunikasi yang terjalin selama ini hanya sebatas ketika peternak mendapat kendala dalam peternakannya.

\section{Evaluasi process}

Evaluasi process merupakan evaluasi yang bertujuan untuk mengidentifikasi kesesuaian jalanya progam berdasarkan ketentuan-ketentuan yang telah dibuat selama kemitraan berlangsung

Tabel 3. Evaluasi process kemitraan PT Gombek Boer Indonesia

\begin{tabular}{|c|c|c|c|c|c|c|}
\hline \multirow{2}{*}{$\mathrm{X}_{3}$ (Process) } & \multicolumn{4}{|c|}{ Skor Likert } & \multicolumn{2}{|c|}{ Rata-rata } \\
\hline & 1 & 2 & 3 & 4 & 5 & \\
\hline $\begin{array}{l}\mathrm{X}_{3.1} \text { Kinerja peternak dalam memenuhi target } \\
\text { standart perusahaan }\end{array}$ & - & - & 14 & 49 & - & 3,77 \\
\hline $\mathrm{X}_{3.2}$ Kesesuaian pelaksanaan kemitraan & - & 39 & 24 & - & - & 2,38 \\
\hline $\mathrm{X}_{3.3}$ Pengawasan lapang oleh PPL & - & 49 & 14 & - & - & 2,22 \\
\hline Rata-rata & & & & & & 3,52 \\
\hline $\begin{array}{l}1=\text { sangat buruk } \\
3=\text { cukup baik } \\
5=\text { sangat baik }\end{array}$ & $\begin{array}{l}2=b \\
4=b\end{array}$ & & & & & \\
\hline
\end{tabular}

Target yang harus dicapai oleh peternak telah tertera dalam surat perjanjian kemitraan, isi surat perjanjian kemitraan adalah sebagai berikut :
1. Pembelian dilakukan jika cempe dalam keadaan sehat (tidak sakit)

2. Pembelian dilakukan maksimal pada saat berat cempe $20 \mathrm{~kg}$ dan atau umur cempe 4 bulan. 
Kinerja peternak dalam memenuhi target perusahaan mendapatkan nilai baik dengan rata-rata 3,77 . Semangat dalam meningkatkan kualitas hasil produksi dapat didorong dengan memberikan pelayanan baik, sarana dan prasarana yang baik, serta membuat kesepakatan harga yang disesuaikan dengan harga pasar atau adanya pemberian bonus ketika hasil produksi bagus.

Kesesuaian pelaksanaan kemitraan nilai rata-rata 2,38 dan $62 \%$ peternak mengatakan bahwa dalam pelaksanaan kemitraan masih terdapat banyak ketidaksesuaian. Ketidaksesuaian pelaksanaan kemitraan dimulai dari:

1. Tidak ditandatanganinya kontrak kerja kemitraan atau surat perjanjian kemitraan yang didalamnya mencakup hak dan kewajiban, perjanjian- perjanjian serta sangsi.

2. Kelompok peternak yang seharusnya melakukan pembelian cempe dari peternak sudah tidak lagi dilakukan dengan alasan pihak kelompok peternak mengatakan kurang efisien apabila pembelian cempe harus melewati kelompok peternak.
3. Pembelian cempe dari perusahaan kepada peternak tidak sesuai jadwal atau perusahaan terlambat dalam pembelian cempe.

4. Peternak melakukan penjualan ternak diluar PT Gombek Boer Indonesia.

Ketidaksesuaian pelaksanaan kemitraan disebabkan oleh manajemen perusahaan yang masih belum stabil. Selanjutnya pengawasan lapang merupakan salah satu strategi umum yang digunakan oleh lembaga kemitraan untuk pendampingi peternak setiap periode produksi guna meningkatkan mutu dan kualitas sumber daya manusia. Sebanyak $78 \%$ peternak mengatakan bahwa pengawasan lapang kurang baik. Hal ini dikarenakan PPL yang bertugas tidak rutin mengunjungi peternak, PPL hanya mengunjungi peternak ketika ada permasalahan atau hanya ketika peternak membutuhkan.

\section{Evaluasi product}

Evaluasi product merupakan evaluasi yang untuk melihat sejauh mana hasil yang telas dicapai pada progam kemitraan berdasarkan tujuan, konteks, input, dan proses, dan manfaat program.

Tabel 4. Evaluasi Product kemitraan PT Gombek Boer Indonesia

\begin{tabular}{|c|c|c|c|c|c|c|}
\hline \multirow{2}{*}{$\mathrm{X}_{4}$ (Product) } & \multicolumn{4}{|c|}{ Skor Likert } & \multicolumn{2}{|c|}{ Rata-rata } \\
\hline & 1 & 2 & 3 & 4 & 5 & \\
\hline $\begin{array}{l}\text { X.1 Kemampuan peternak dalam meningkatan } \\
\text { jumlah dan kualitas produksi ternak }\end{array}$ & - & - & 9 & 43 & 11 & 4,01 \\
\hline $\begin{array}{l}\text { X.2 Peningkatan pendapatan dan kepuasan } \\
\text { peternak dalam progam kemitraan }\end{array}$ & - & - & - & 40 & 23 & 4,36 \\
\hline $\mathrm{X}_{4.3}$ Resiko usaha & - & - & 16 & 47 & - & 3,74 \\
\hline $\mathrm{X}_{4.4}$ Ketepatan pembelian hasil ternak & - & 49 & 14 & - & - & 2,22 \\
\hline $\mathrm{X}_{4.5}$ Keinginan kontinuitas kerjasama & - & - & - & 38 & 25 & 4,26 \\
\hline $\mathrm{X}_{4.6}$ Saling menguntungkan & - & - & 44 & & 19 & 4,39 \\
\hline Rata-rata & & & & & & 3,83 \\
\hline $\begin{array}{l}1=\text { Sangat rendah } \\
3=\text { cukup tinggi } \\
5=\text { sangat tinggi }\end{array}$ & $\begin{array}{l}2= \\
4=\end{array}$ & dah & & & & \\
\hline
\end{tabular}

Peningkatan produktifitas dan jumlah ternak yang dimiliki oleh peternak selama kemitraan mendapatkan nilai 4,01 dengan rata-rata $68 \%$ peternak menjawab bahwa dengan mengikuti kemitraan berpengaruh terhadap jumlah dan kualitas ternak yang dimiliki oleh peternak. Selanjutnya mengenai peningkatan pendapatan merupakan aspek penting yang inginkan oleh peternak dari usaha ternaknya. Banyak keuntungan yang 
dirasakan peternak selama mengikuti kemitraan dengan PT Gombek Boer Indonesia dilihat dari rata-rata penilaian peternak sebesar 4,36, namun sayangnya peningkatan pendapatan dan daya tawar yang dirasakan peternak belum berpengaruh terhadap kepuasan peternak. Peternak berharap adanya perbaikan dari sistem pembelian ternak hasil produksi dari perusahaan karena berdampak langsung terhadap perekonomian peternak.

Resiko usaha dalam kemitraan sering kali terjadi disebabkan berbagai macam penyebab. Resiko usaha dalam kemitraan yang dijalankan oleh PT Gombek Boer Indonesia mendapatkan nilai rata-rata 3,74. Peternak menjawab resiko usaha ditanggung bersama antara PT Gombek Boer Indonesia dan peternak. Resiko dalam kemitraan akan semakin tinggi ketika tidak terdapat kejelasan surat perjanjian antara perusahaan mitra dengan peternak mitra yang mengikat. Ketepatan pembelian hasil ternak yang dilakukan oleh PT Gombek Boer Indonesia mengalami keterlambatan, $82 \%$ peternak mengatakan bahawa perusahaan telat dalam melakukan sistem pembayaran kepada peternak. Keterlambatan pembelian ternak disebabkan pada awal pembentukan kemitraan PT Gombek Boer Indonesia belum mengetahui sasaran pasar kambing Boerja dengan tepat.

Kemitraan antara PT Gombek Boer Indonesia dan peternak kambing yang telah terjalin dan masih berlangsung diharapkan dapat terus berkelanjutan. Rasa saling membutuhkan dan saling menguntungkan dari masing-masing pihak diharapkan mampu menjadi pendorong agar seluruh pihak yang terlibat dalam kemitraan dapat saling menjaga komitmen yang telah disepakati, $60 \%$ peternak mengatakan bahwa masih ingin bermitra dengan PT Gombek Boer Indonesia. Selanjutnya keuntungan merupakan tujuan utama terbentuknya sebuah kemitraan. Keuntungan tidak hanya ingin dirasakan oleh petani tetapi juga perusahaan mitra selaku pelaku usaha yang menawarkan kemitraan. Berdasarkan hasil penelitian $70 \%$ peternak yang mengikuti kemitraan pekerjaan peternak merupakan pekerjaan samping jadi dengan hasil dari peternakan dapat membantu memenuhi kebutuhan rumah tangga peternak.
Sedangkan keuntungan yang dirasakan oleh PT Gombek Boer Indonesia selama berjalannya kemitraan hasil produksi ternak dari peternak yang baik sehingga kontinuitas hasil terus ada.

\section{KESIMPULAN}

Evaluasi context kemitraan PT Gombek Boer Indonesia mendapat nilai baik kecuali pada perencanaan progam pelatihan dan pembinaan peternak karena untuk saat ini tidak ada progam pelatihan yang diberikan oleh PT Gombek Boer Indonesia dan perencanaan pemasaran karena pemasaran yang dilakukan oleh PT Gombek Boer Indonesia masih belum maksimal. Pada evaluasi input yang mendapatkan nilai buruk yaitu adanya komunikasi terbuka antara peternak dengan perusahaan mitra dikarenakan komunikasi yang dilakukan oleh PT Gombek Boer Indonesia kurang maksimal, hanya dilakukan ketika ada permasalahan yang terjadi. Evaluasi process, kesesuaian pelaksanaan kemitraan mendapat nilai buruk karena banyak terdapat kecurangan yang dilakukan oleh peternak dan ketidak tegasan PT Gombek Boer Indonesia dalam menindaklanjuti. Pengawasan lapang oleh PPL mendapat nilai buruk karena PPL yang bertugas hanya mengunjungi peternak ketika ada permasalahan dan ketika kambing milik peternak ingin dikawinkan. Evaluasi product mendapat nilai baik kecuali ketepatan pembelian hasil ternak karena PT Gombek Boer Indonesia mendapat kesulitan dalam melakukan pemasaran sehingga pembelian ternak ke peternak mitra menjadi terlambat.

\section{DAFTAR PUSTAKA}

Direktorat Jenderal Peternakan dan Kesehatan Hewan. 2017. Statistik Peternakan dan Kesehatan Hewan Tahun 2017. Jakarta (damID): Ditjennak

Hafsah, J. 2000. Kemitraan Usaha Konsepsi dan Strategi. Pustaka Sinar Harapan, Jakarta.

Hartono, B. 2012. Ekonomi Bisnis Peternakan. UB Press. Malang.

Makka, D. 2004. Tantangan dan Peluang Pengembangan Agribisnis Kambing Ditinjau dari Aspek Pewilayahan 
Sentra Produksi. Pros. Lokakarya Nasional Kambing Potong. Bogor, 6 Agustus 2004. Puslitbang Peternakan dan Loka Penelitian Kambing Potong. $3-14$.

Mardikanto, T. 2009. Sistem Penyuluhan Pertanian. Sebelas Maret University Press. Surakarta.

Mulyani.2017. Anaslisi Kemitraan Usaha Tomat di Lembang Jawa Barat (Studi Kasus Kelompok Usahatani Mekar Tani Jaya).(Tesis).

Pascasajana, Institut Pertanian Bogor. Bogor

Muryadi, Agustanico Dwi. 2017. Model

Evaluasi Program Dalam

Penelitian Evaluasi. Jurnal IImiah PENJAS. ISSN: 2442-3874. 3. 1.

Syawal, Muhammad. 2010. Karakterisktik Morfologi Dan Produksi kambing Boer, Kacang Dan Persilangannya pada Umur 0-3 Bulan (PraSapih). Seminar Nasional Teknologi Peternakan dan Veteriner 2010. Loka Penelitian Kambing Potong, Sei Putih. 616-620.

Sumardjo, Jaka Sulaksana, Wahyu A. Darmono. 2004. Teori dan Praktik Kemitraan Agribisnis. Penebar Swadaya. Jakarta.

Zakaria, F. 2015. Pola Kemitraan Agribisnis. Ideas Publishing. Gorontalo. 